\title{
Sikap Pembudidaya dalam Penyuluhan Kualitas Air untuk Budidaya Ikan di Desa Kertayasa, Kecamatan Cijulang, Kabupaten Pangandaran
}

\section{Attitude of Aquaculturist towards The Importance of Water Quality for Fish Cultre During Field Communication in Kertayasa Village, Cijulang, Pangandaran District}

\author{
Roffi Grandiosa ${ }^{1 *}$, Rioaldi Sugandhy ${ }^{1}$, Anggi Nugraha ${ }^{2}$
}

* Korespondensi Penulis:

\section{Roffi Grandiosa}

E-mail: roffi.grandiosa@unpad.ac.id

${ }^{1}$ Laboratorium Akuakultur, Fakultas

Perikanan dan Ilmu Kelautan

Universitas Padjadjaran

${ }^{2}$ Mahasiswa Prodi Perikanan

PSDKU Unpad Pangandaran

Submitted July 29, 2020.

Revised Aug 4, 2020.

Accepted Aug 25, 2020.

\section{Abstract}

The success of freshwater aquaculture pratices in the Pangandaran District depends on the knowledge of the farmers to support sustainable aquaculture production. One of the main constraints is the water quality that often become the culprit for the low production in the area. The aquaculture farmers in Kertayasa Village are organized in the Kawungsari Group and were quite established in Pangandaran as they are known for Gouramy (Osphronemus gouramy) culture and now has expanded their practices upon other species such as Pangasius (Pangasius hypophthalmus) and Tilapia (Oreochromis niloticus). However, the knowledge of water quality management in regards to successful aquaculture has not been quite developed. The initative to inform and direct farmers regarding the knowledge of water quality has brought a positive result where farmers were now quite aware on the important factors of water quality such as ammonia, temperature and $\mathrm{pH}$ to support the production of fish. Further, the knowledge regarding water quality must be repeatedly given with enhancement on practical guide in handling measurement kits. Therefore the success of aquaculture in rural areas rely on best practices knowledge to empower community development.

Keywords: Aquaculture, Water Quality, Pangandaran, Community Development

\section{Abstrak}

Keberhasilan budidaya air tawar di wilayah Pangandaran sangat tergantung kepada pengetahuan pembudidaya dalam melakukan budidaya ikan yang berkelanjutan. Salah satu hambatan adalah pengetahuan mengenai kualitas air yang sering kali dituduh sebagai hal yang menyebabkan permasalahan rendahnya produksi budidaya. Pembudidaya di Desa Kertayasa yang tergabung dalam kelompok pembudidaya Kawungsari telah dikenal di Pangandaran sebagai kelompok pembudidaya yang cukup sukses mengembangkan budidaya Gurame dan saat ini telah mengembangkan pula spesies akuakultur lain yakni Pangasius dan Tilapia. Salah satu hambatan utama yakni pengetahuan mengenai akuakultur yang masih kurang terutama tentang manajemen kualitas air. Hal ini sangat mendukung keberhasilan budidaya namun pengetahuan tersebut layak ditingkatkan. Inisiasi untuk melakukan penyuluhan dan mengarahkan pembudidaya sangat direspon positif oleh pembudidaya sehingga saat ini pembudidaya mengetahui mengenai faktor penting dalam kualitas air yakni ammonia, suhu dan $\mathrm{pH}$ yang terkait produksi ikan. Selanjutnya, pengetahuan mengenai kualitas air harus diberikan berulangkali terutama dengan focus metoda praktis dalam mempraktekkan alat pengukur kualitas air. Pada akhirnya, keberhasilan budidaya ikan di pedesaan sangat bergantung dengan metoda aplikasi yang baik sehingga dapat memperkuat perkembangan komunitas pembudidaya.

Kata Kunci: Budidaya, Kualitas Air, Pangandaran, Perkembangan Komunitas

\section{Pendahuluan}

Desa Kertayasa berada di wilayah Kecamatan Cijulang Pangandaran. Jarak desa 
Kertayasa ke Ibukota Kecamatan sejauh $1 \mathrm{Km}$ sedangkan jarak ke Ibukota Kabupaten sejauh $5 \mathrm{Km}$. Desa Arjasari memiliki luas wilayah 1.355.610 Ha yang terdiri dari 3 dusun yakni Dusun Bugel, Dusun Tenjolaya dan Dusun Karangpancing. Desa Kertayasa adalah desa yang memegang erat prinsip dan budaya yang sudah ada. Hal ini dapat dibuktikan dengan masih adanya keyakinan masyarakat untuk tetap mempertahankan keberadaan balong (kolam ikan pekarangan) di dekat rumah mereka. Secara sosiologis dan antropologis kolam pekarangan mengandung pengertian sosial, ekonomi dan budaya. Dari segi sosial dapat meningkatkan dan atau menjaga prestise, dari segi ekonomi dapat menambah pendapatan rumah tangga dan dari segi budaya kolam pekarangan yang juga berfungsi sebagai tempat mandi, cuci, kakus (MCK) umum sebagai sarana untuk bertemu, berkumpul sambil membincangkan sesuatu yang menjadi kebiasaan mereka. Secara ekologis, kolam pekarangan merupakan suatu sistem daur ulang dengan mata rantai manusia ternak - ikan - tumbuhan (Soemarwoto, 1983). Masyarakat cukup meyakini bila keberadaan balong dilestarikan untuk memelihara ikan, maka akan menjadi pintu rejeki bagi mereka atau ikan ini juga dapat menjadi cadangan pangan disaat saat tertentu.

Kegiatan perikanan di Desa Kertayasa saat ini mulai bergeser dari kolam pekarangan menjadi sebuah unit usaha yang dilakukan para kelompok tani untuk mendapatkan tambahan penghasilan selain kegiatan sehari-hari seperti berternak sapi atau pekerjaan wirausaha di bidang wisata. Aktivitas-aktivitas yang berawal dari ide atau dari sumber penyuluhan dari Dinas Perikanan yang mampu dilaksanakan secara mikro ataupun kedepannya secara makro sebetulnya dapat menunjang pembangunan (Koentjaraningrat 1985). Sistem nilai yang dianut suatu masyarakat kemudian diwujudkan dalam suatu kegiatan baik untuk kepentingan individual maupun kepentingan kolektif. Kegiatankegiatan yang berpola tersebut dilaksanakan secara berkesinambungan, sehingga merupakan suatu aktivitasaktivitas yang terlembagakan (Suwartapradja 2005). Sebagaimana yang terlihat di Desa Kertayasa, dimana aktivitas budidaya perikanan sudah terlembagakan dalam kelompok pembudidaya Kawungsari bahkan sudah diapresiasi oleh pemerintah melalui penghargaan Juara 3 Unit Pembenihan Rakyat bidang budidaya perikanan Kementrian Kelautan Perikanan pada tahun 2014 (kkp.go.id 2014).

Beberapa kegiatan perikanan yang dilakukan saat ini antara lain budidaya ikan nila, gurame, patin, dan mina padi. Kegiatan pemijahan belum banyak dilakukan oleh kelompok tani di wilayah Desa Kertayasa yakni budidaya ikan gurame namun ini karena beberapa kendala antara lain kematian induk dan perlunya pengadaan induk kembali. Pendederan ikan budidaya sangat dipengaruhi oleh kualitas air yang terkadang menghambat produksi maka diperlukan berbagai tambahan pengetahuan yang baik untuk pengelolaan kualitas air. Budidaya ikan khususnya pendederan dan pembesaran ikan yang dikembangkan yakni ikan Gurami (Osphronemus gourami), ikan nila (Oreochromis niloticus) serta ikan Patin (Pangasius hypopthalmus) merupakan spesies penting dalam perikanan budidaya saat ini yang telah berkembang pesat di masyarakat. Selain sudah memasyarakat, budidaya ikan tersebut relatif mudah dilakukan.

Kegiatan pendidikan dan pelatihan dilakukan untuk memberikan gambaran secara langsung berbagai aspek kualitas air dalam menunjang budidaya ikan sehingga masyarakat memiliki berwawasan agribisnis yang lebih kuat. Salah satu kendala dalam budidaya ikan nila selain ketersediaan akan benih yang mencukupi adalah kualitas air (Islami et al. 2017). Faktor penting yang perlu diperhatikan dalam menunjang keberhasilan budidaya ikan adalah penyediaan lingkungan yang sesuai dengan benih, sehingga diperoleh kelangsungan hidup yang tinggi. Benih ikan harus mendapatkan perhatian terutama pengendalian kondisi lingkungan akuakultur agar tetap stabil dan optimal bagi benih ikan sebagai hewan budidaya manjadi sangat perlu dilakukan mengingat kualitas air yang kurang baik dapat menimbulkan stress, memicu timbulnya penyakit, dan juga dapat menyebabkan kematian pada ikan yang dibudidaya (Hasan 2015).

Metode penelitian untuk mengetahui sikap atau tingkat pengetahuan tentang kualitas air adalah dengan metode penyuluhan yakni sebuah prosedur untuk mencapai sebuah tujuan secara sistematik dengan menggunakan teknik penyuluhan yang telah direncanakan. Metode penyuluhan tidak hanya diperoleh dari seorang penyuluh, namun juga dapat diperoleh dari pelatihan-pelatihan dengan berbagai sumber. Penelitian ini sangat diperlukan untuk mengetahui lebih jauh mengenai berbagai metode penyuluhan yang pernah ditempuh oleh setiap anggota kelompok. Penelitian ini juga bermaksud untuk mengetahui sikap yang ditunjukkan oleh anggota kelompok terhadap metode penyuluhan yang pernah diterima dalam pelatihan atau penyuluhan. Tujuan yang ingin dicapai pada pengabdian ini adalah 1) mengetahui sikap yang ditunjukkan oleh anggota kelompok "Kawungsari" terhadap metode penyuluhan perikanan, 2) mengetahui jenis metode penyuluhan yang pernah di terima oleh anggota kelompok "Kawungsari", 3) melihat hubungan antara metode penyuluhan yang pernah diterima oleh setiap anggota terhadap sikap anggota kelompok "Kawungsari". Kegiatan ini diharapkan dapat memberikan motivasi bagi masyarakat khususnya pemuda sehingga mereka tergerak untuk melakukan usaha monitoring kualitas air secara mandiri. Selanjutnya diharapkan dapat meningkatkan pendapatan masyarakat dengan menciptakan lapangan kerja sendiri dan di wilayah tempat tinggal mereka. Manfaat dari kegiatan penyuluhan ini adalah melalui 
kegiatan pemberdayaan masyarakat dengan pendekatan ekonomi masyarakat diharapkan dapat mengembangkan potensi desa dan sumberdaya pemuda yang bersangkutan, dan juga dapat menghasilkan berbagai produk unggulan dari potensi perikanan dan dengan pendampingan manajemen dan kewirausahaan serta teknologi tepat guna yang mengarah pada peningkatan mutu atau kualitas produk, tentu hal ini akan semakin meningkatkan peran pemuda/masyarakat desa tersebut dalam rangka meningkatkan pendapatan masyarakat desa.

\section{Materi dan Metode Pelaksanaan}

\section{Waktu dan Tempat Penelitian}

Penelitian dilaksanakan dari Bulan Mei sampai Juli 2019 berlokasi di Desa Kertayasa, Kecamatan Cijulang, Kabupaten Pangandaran. Penentuan lokasi pada penelitian ini ditentukan secara sengaja atau purposive di Desa Kertayasa. Desa ini mayoritas penduduknya berprofesi sebagai pembudidaya, peternak dan pembudidaya ikan sehingga wilayah ini merupakan salah satu penyumbang hasil pertanian, perikanan dan peternakan. Pembudidaya yang dijadikan sampel dalam penelitian ini adalah pembudidaya ikan.

Aktivitas yang dilakukan sebelum penelitian yaitu penyuluhan. Kegiatan in dapat didefinisikan sebagai kegiatan belajar sambil bekerja atau mempraktekannya (learning by doing). Hasil dari kegiatan penyuluhan adalah membawa perubahan dalam hal pengetahuan (knowledge), cara berpikir (thinking), kecakapan (skill) dan perasaan atau sikap (Hikmat 2001). Proses mempercepat pencapaian tujuan dengan pendidikan dan pelatihan harus dapat menyampaikan pesan perubahan secara efektif dan efisien sehingga dibutuhkan proses komunikasi yang sesuai dengan kebutuhan sasaran, sumber pesan yang dapat dipercaya, saluran penyampaian, pemberi pesan dan umpan balik. Pemberian materi yang diberikan berkaitan dengan aspek kualitas air pada budidaya ikan air tawar agar dapat menunjang kebutuhan sasaran, yakni aspek pengenalan kualitas air, aspek sumberdaya manusia dan aspek pengelolaan kualitas air.

Poses pelaksanaan kegiatan, tahap persiapan merupakan tahap yang cukup penting. Persiapan yang dilakukan dalam kegiatan penyuluhan ini dimulai dengan persiapan secara administratif meliputi persiapan proposal, surat tugas, surat perijinan kegiatan. Sebelum dilakukan kegiatan Pengabdian Kepada Masyarakat Mandiri ini terlebih dahulu tim melakukan survey lapangan guna menentukan lokasi pelaksanaan kegiatan dan sasaran yang akan menjadi peserta dalam kegiatan pengabdian ini. Setelah ditentukan kelompok sasaran tim melakukan diskusi dengan ketua kelompok membahas rencana program dan materi yang akan disampaikan sehingga apa yang akan disampaikan sesuai dengan kebutuhan kelompok target sasaran.

\section{Tahap Pelaksanaan Kegiatan}

Tahapan pelaksanaan kegiatan yang telah dilakukan terdiri dari 2 tahap yaitu pemberian penyuluhan secara langsung mengenai penjelasan teknologi peningkatan kualitas air terhadap kesehatan budidaya ikan dan tahap terakhir adalah tahap evaluasi dan monitoring kegiatan.

\section{Pemberian Materi Diseminasi Teknologi Peningkatan Kualitas Air untuk Budidaya}

Ceramah atau seminar merupakan proses introduksi pengetahuan dari pemberi ceramah kepada khalayak sasaran. Pengetahuan yang disampaikan dalam kasus ini adalah pengenalan berbagai macam parameter kualitas air, pengenalan metoda mengukur kualitas air serta pengelolaan kualitas air. Pemberi ceramah adalah Dosen pada Departemen Perikanan Fakultas Perikanan dan Ilmu Kelautan Universitas Padjadjaran. Khalayak sasarannya adalah anggota kelompok tani Desa Kertayasa Kecamatan Cijulang yang memang salah satu kegiatannya adalah melakukan kegiatan budidaya ikan. Kegiatan ceramah telah dilaksanakan pada tanggal 13 Februari 2020, bertempat di Balai Pertemuan Kelompok Pembudidaya Kawungsari, Kecamatan Cijulang. Kegiatan ceramah ini berlangsung mulai dari pukul 10.00 sampai dengan 13.00 WIB. Peserta yang mengikuti kegiatan ini sekitar 70 orang. Suasana keakraban tetap terjaga selama penyampaian materi berlangsung sebagaimana terlihat pada Gambar 1.

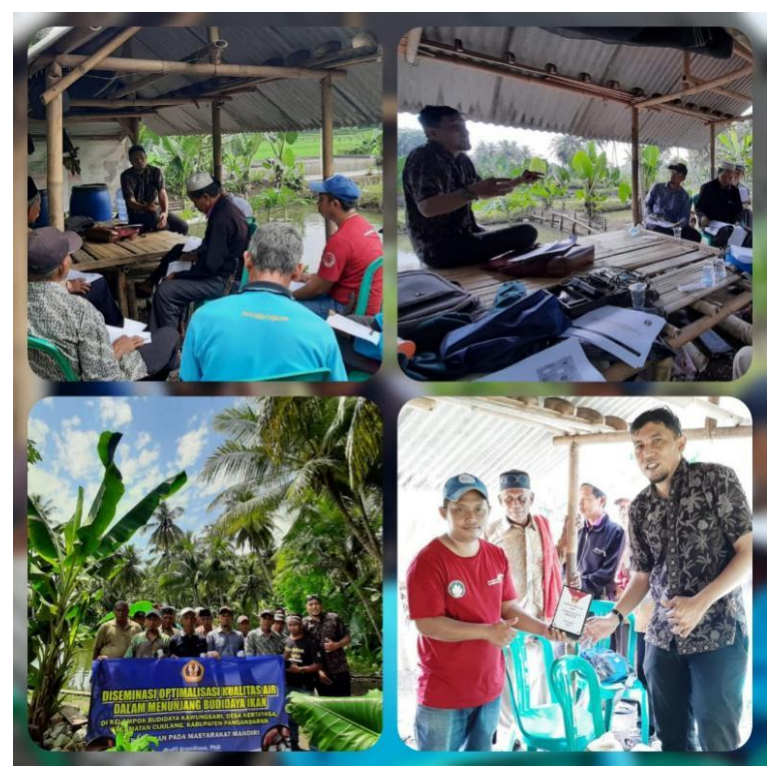

Gambar 1 kegiatan penyuluhan di Desa Sindangkerta, Kecamatan Cijulang

Akhir dari kegiatan penyampaian materi adalah diskusi. Diskusi dimaksudkan untuk lebih mempertajam pesan yang telah disampaikan saat ceramah. Berbagai pertanyaan dan pendapat dilontarkan oleh para peserta sehingga suasana pertemuan terasa akrab dengan semangat kekeluargaan. Banyaknya pertanyaan dan lontaran pendapat tersebut menunjukkan bahwa materi 
yang disampaikan dapat dikatakan telah tersampaikan kepada objek sasaran dengan baik.

\section{Metode Pengumpulan Data}

Data dan keterangan yang dibutuhkan dalam penelitian ini dikumpulkan melalui data primer merupakan data yang diperoleh secara langsung dari sumbernya, diamati, dan dicatat untuk pertama kalinya.

\section{Metode Pengambilan Sampel}

Penentuan populasi dalam penelitian ini adalah dengan cara purposive sampling, yaitu semua anggota kelompok pembudidaya kawungsari di Desa Kertayasa. Penentuan sampel dalam penelitian ini adalah dengan menggunakan proportionate random sampling. Jumlah anggota pembudidaya adalah sebesar 70 orang oleh karena itu penentuan sampel dalam penelitian ini menggunakan rumus Slovin (Silalahi 2015), dengan rumus sebagai berikut:

$$
\mathrm{n}=\frac{\mathrm{N}}{1+\mathrm{Ne}^{2}}
$$

Keterangan:

$$
\begin{array}{ll}
\mathrm{N} & =\text { ukuran sampel } \\
\mathrm{N} & =\text { ukuran populasi; } \\
\mathrm{e}^{2} & =15 \% .
\end{array}
$$

Sehingga didapatkan:

$$
\mathrm{n} \quad=27 \text { orang. }
$$

\section{Metode Analisis Data}

Metode pengukuran yang digunakan dalam penelitian ini adalah dengan menggunakan metode analisis kualitatif (deskriptif) yang melalui empat tahap, yaitu 1) tahap pengumpulan data, 2) tahap reduksi data, 3) tahap penyajian data, dan 4) tahap penarikan kesimpulan. Alat ukur yang digunakan dalam penelitian ini adalah menggunakan skala Likert yaitu setiap pertanyaan yang diberikan mendapatkan skor sesuai dengan pilihan responden. Skor yang diberikan berbeda tergantung pada setiap jawaban yang tersedia. Skor untuk masing-masing responden dijumlahkan untuk mengetahui sikap pembudidaya dalam menerima materi dan media penyuluhan. Sikap pembudidaya dalam menerima materi dan media didapatkan dengan menggunakan persamaan:

$$
\frac{\text { Total skor }}{\text { Skor maksimum }} \times 100 \%
$$

\section{Hasil dan Pembahasan}

\section{Gambaran Umum Kegiatan}

Program pengabdian pada masyarakat (PKM) berupa penjelasan mengenai Diseminasi Teknologi Peningkatan Kualitas Air untuk Kesehatan Ikan Budidaya yang sudah dilaksanakan ini diharapkan dapat menambah pengetahuan, keterampilan dan rasa percaya diri untuk melakukan kegitan budidaya sehingga dapat meningkatkan pendapatan para anggota kelompok tani. Para peserta pelatihan akan lebih semangat dan termotivasi untuk mengembangkan diri. Hasil pelatihan ini akan bermanfaat bagi diri mereka masing-masing dalam mengembangkan teknik budidaya ikan nila. Hasil kegiatan PKM secara garis besar mencakup beberapa komponen sebagai berikut:

1. Keberhasilan target jumlah peserta pelatihan

2. Ketercapaian tujuan pelatihan

3. Ketercapaian target materi yang telah direncanakan

4. Kemampuan peserta dalam penguasaan materi

Kemampuan peserta dilihat dari penguasaan materi masih kurang dikarenakan waktu yang singkat dalam penyampaian materi dan kemampuan para peserta yang berbeda-beda. Hal ini disebabkan jumlah materi yang banyak hanya disampaikan dalam waktu sehari sehingga tidak cukup waktu bagi para peserta untuk memahami dan mempraktekkan secara lengkap semua materi yang diberikan. Oleh karena itu setelah kegiatan pemberian materi ini akan dilakukan monitoring dan evaluasi dengan cara mendatangi tempat kelompok tani tersebut melakukan kegiatan budidaya ikan air tawar.

\section{Sikap Pembudidaya Ikan dalam Menerima Materi Penyuluhan \\ Sikap pembudidaya dalam menerima sifat materi.}

Sifat materi penyuluhan harus tersedia dalam jangkauan pembudidaya dan materi penyuluhan harus sesuai dengan kebutuhan pembudidaya sehingga materi bermanfaat dan dapat diimplementasikan. Tanggapan responden terhadap indikator sikap pembudidaya dalam menerima sifat materi semuanya menerima yaitu sebesar 27 jiwa (100\%).

\section{Sikap pembudidaya dalam menerima bidang yang disampaikan.}

Materi yang disampaikan memiliki beberapa bidang seperti teknik budidaya dan dinamika kelompok. Sikap pembudidaya dalam menerima bidang yang disampaikan dapat dilihat pada tabel berikut. Tanggapan responden terhadap indikator sikap pembudidaya dalam menerima bidang yang disampaikan semuanya dapat menerima yaitu sebesar 27 responden atau $100 \%$.

\section{Sikap pembudidaya dalam menerima kelayakan materi.}

Materi yang disampaikan harus berasal dari sumber-sumber yang dapat dipercaya agar secara teknis dapat diterapkan sehingga materi layak untuk disampaikan. Tanggapan responden terhadap indikator sikap pembudidaya dalam menerima kelayakan materi adalah sebanyak 27 responden dengan persentase $100 \%$.

Sikap Pembudidaya Ikan dalam Menerima Media 


\section{Penyuluhan}

Sifat media harus sederhana dan mengemukakan ide-ide baru sehingga pembudidaya lebih mudah untuk memperhatikan, mengingat, mencoba, dan menerima ideide baru yang dikemukakan. Tanggapan responden terhadap indikator sikap pembudidaya dalam menerima sifat media penyuluhan dapat menerima yaitu sebesar 27 responden atau $100 \%$ menerima. Adapun media penyuluhan yang digunakan oleh penyuluh dari Unpad dalam pemberian materi kepada responden.

\section{Sikap pembudidaya dalam menerima jenis media penyuluhan}

Jenis media yang digunakan harus sesuai dengan kondisi di lapangan sehingga penyampaian materi dapat diberikan dengan lebih baik. Tanggapan responden terhadap indikator sikap pembudidaya dalam menerima jenis media penyuluhan yang dapat menerima yaitu sebesar 25 responden atau $92.59 \%$, sedangkan yang kurang menerima hanya 2 responden dengan persentase $7.34 \%$.

Hasil penelitian menunjukkan bahwa sikap pembudidaya dalam menerima materi penyuluh masuk kategori menerima. Hal ini dapat terlihat dari pembudidaya yang menerima dengan baik materi-materi yang disampaikan oleh penyuluh. Menurut pembudidaya, materi yang disampaikan penyuluh mudah dipahami. Selain itu juga materi yang disampaikan penyuluh sesuai dengan kebutuhan pembudidaya. Seperti teknis budidaya yang baik dan benar misalnya penggunaan benih ikan yang bervarietas unggul, pengolahan lahan yang baik dan benar, pengelolaan kualitas air yang baik, pengendalian hama dan penyakit ikan secara terpadu, serta pemanenan yang tepat dan juga teknologi-teknologi yang baru di bidang perikanan. Penyuluh saat ini mampu mempraktekkan langsung di lapangan, sehingga pembudidaya lebih yakin dengan materi yang disampaikan.Sebagaimana dengan hasil penelitian yang dilakukan Hutabarat (2011) syarat-syarat yang harus dimiliki oleh materi penyuluhan adalah harus sesuai dengan potensi desa, berbiaya murah, dan menguntungkan secara nyata. Media yang digunakan oleh penyuluh cenderung media yang sederhana agar dapat dengan mudah dimengerti oleh pembudidaya. Sikap pembudidaya terhadap materi dan media penyuluhan adalah positif. Tiga indikator sikap pembudidaya dalam menerima materi penyuluhan diuraikan sebagai berikut.

Hasil wawancara dengan responden diperoleh bahwa materi yang disampaikan oleh pemateri kepada responden sudah berbentuk sederhana terutama dalam penggunaan bahasa. Bahasa yang digunakan oleh pemateri mudah dipahami oleh pembudidaya, sehingga pembudidaya mampu memahami materi yang disampaikan. Manfaat dan keuntungan kepada pembudidaya terutama dalam hal peningkatan produksi dan sistem tanam tersebut tidak berdampak negatif bagi lingkungan sehingga dapat diterima di masyarakat dan tidak bertentangan dengan nilai norma yang ada.

Sikap merupakan suatu proses respon dalam wujud menerima atau tidak menerima terhadap suatu objek. Apabila suatu teknologi baru diperkenalkan kepada pembudidaya maka akan mempengaruhi sikapnya. Hal tersebut diperkuat dengan hasil dari wawancara yang menunjukkan bahwa tanggapan responden dalam menerima indikator sikap pembudidaya di bidang materi yang disampaikan semuanya dapat menerima. Indikator sikap pembudidaya dalam menerima bidang yang disampaikan menghasilkan tanggapan yang positif. Materi yang disampaikan oleh penyuluh seperti cara pengelolaan kolam, perawatan ikan, monitorin kualitas air serta cara budidaya ikan secara baik pada umumnya sudah dapat diterima dengan baik oleh pembudidaya, karena rata-rata pembudidaya di lokasi penelitian sudah berpengalaman. Walaupun begitu, beberapa hal yang perlu ditingkatkan adalah dalam bidang pengendalian hama penyakit ikan. Materi yang disampaikan oleh penyuluh terkait dengan pengendalian hama penyakit masih kurang memuaskan, untuk mengatasi penyakit yang diakibatkan bakteri.

Hasil wawancara di lapangan menunjukkan penyuluh telah memenuhi keinginan pembudidaya walaupun tidak semuanya akan tetapi perhatian penyuluh pada pembudidaya sangat baik. Pada dinamika kelompok pembudidaya, seorang penyuluh dapat menumbuhkan semangat dalam kegiatan kelompok. Materi yang disampaikan penyuluh dimasa mendatang harus diperhatikan keberlanjutannya mengingat jika terlaksana akan dapat membimbing kelompok pembudidaya dalam jangka panjang sehingga usaha yang dijalankan makin berkembang.

Dalam menyiapkan materi penyuluhan, maka materi itu harus memiliki kelayakan, yaitu: harus sesuai dengan potensi wilayah, harus menguntungkan secara nyata, hasil dari pelaksanaan kegiatan penyuluhan dapat dirasakan manfaatnya oleh pembudidaya di daerah penelitian tersebut. Terlihat dari peningkatan hasil dan pendapatan pembudidaya dan isi materi yang disampaikan harus berbiaya murah. Materi yang disampaikan secara teknis dapat diterapkan oleh pembudidaya, seperti cara mengelola kualitas air. Hasil penelitian yang diperoleh, rata rata pembudidaya masih sulit menerapkan di lapangan karena mengingat peralatan kualitas air belum dimiliki secara lengkap.

Hasil penelitian menunjukkan bahwa media penyuluhan cukup baik. Menurut pembudidaya, media yang disampaikan penyuluh sudah menggunakan media yang tepat yaitu menggunakan media cetak (buku, brosur, leaflet, dan handout). Selain itu materi yang disampaikan dalam media tersebut berisi materi-materi yang memang dibutuhkan oleh pembudidaya untuk menunjang usaha budidaya ikan. Penggunaan bahasa yang sederhana tetapi mudah dipahami juga membuat pembudidaya lebih cepat 
mengerti isi yang ingin disampaikan. Selain itu, penyampaian materi yang diselingi dengan video, tidak menimbulkan efek jenuh dan bosan, malah membuat pembudidaya lebih bersemangat mengikuti kegiatan penyuluhan, sehingga menumbuhkan niat untuk memperhatikan, mengingat, mencoba, dan menerima ideide baru yang disampaikan.

Beberapa pertimbangan yakni sifat media penyuluhan dan jenis media penyuluhan. Hasil penelitian menunjukkan bahwa sifat media penyuluhan akan sangat tergantung pada materi yang disampaikan. Media harus berasal dari sumber-sumber yang dapat dipercaya dan dapat dipertanggung jawabkan. Isi materi dalam media yang disampaikan berisi informasi-informasi perikanan yang dibutuhkan pembudidaya. Selain itu juga penyuluh harus menyampaikan materi yang berkaitan dengan inovasi-inovasi baru di bidang perikanan yang dapat menunjang pembudidaya.

Jenis media penyuluhan yang sering digunakan penyuluh antara lain media cetak, audio, dan audiovisual. Penggunaan media ini juga memudahkan penyuluh dalam menyampaikan tujuan yang ingin disampaikan kepada audiens. Hasil wawancara terhadap pembudidaya di Kelurahan Sindangkerta menunjukkan dalam melakukan penyuluhan harus sering menggunakan media cetak dan audio-visual. Media cetak yang sering digunakan seperti brosur, buku, leaflet dan jenis lainnya, dan untuk audio-visual penyuluh menggunakan LCD dan menampilkan berbagai video agar dapat menarik perhatian pembudidaya. Selain itu media yang digunakan, memberikan informasi yang dapat dipercaya oleh pembudidaya. Media cetak yang diberikan penyuluh juga dapat dipelajari oleh pembudidaya sendiri karena isi materi yang diberikan penyuluh menggunakan bahasa yang mudah dipahami oleh pembudidaya.

\section{Masalah-masalah pada Kegiatan Penyuluhan Pertanian}

Masalah-masalah yang dihadapi penyuluhan dalam penyampaian materi dan penggunaan media penyuluhan yaitu:

1. Sulit mengubah perilaku pembudidaya yang tidak mudah menerima ide baru atau inovasi-inovasi baru, sehingga materi yang disampaikan masih kurang bisa diimplementasikan secara langsung.

2. Ketersediaan sarana media penyuluhan yang terbatas sehingga kurang memaksimalkan kegiatan penyuluhan.

\section{Upaya-upaya Mengatasi Masalah dalam Penyuluhan}

Upaya-upaya yang dapat dilakukan penyuluh untuk mengatasi masalah dalam penyampaian informasi dan penggunaan berbagai media penyuluh yaitu:
1. Melakukan pendekatan secara bertahap, melihat karakteristik pembudidaya terlebih dahulu, serta dalam memberikan materi disertai kegiatan praktek di lapangan.

2. Menambah jumlah sarana media penyuluhan yang dibutuhkan dan memaksimalkan sarana yang ada dengan baik dan benar.

\section{Kesimpulan}

Diseminasi teknologi peningkatan kualitas air untuk menunjang kesehatan ikan merupakan pengetahuan/ ketrampilan baru bagi kelompok tani Kawungsari, Desa Kertayasa, Kecamatan Cijulang. Selama pelaksanan kegiatan penyuluhan, dan pelatihan, dapat disimpulkan bahwa para anggota kelompok tani sangat antusias akan informasi dan pengetahuan praktis untuk budidaya ini. Hal ini terlihat mulai sejak mengikuti penyuluhan sampai dengan selesai penyuluhan. Harapannya kelompok tani Desa Kertayasa ini dapat mempraktekan langsung sehingga semakin meningkatkan hasil budidaya dan penghasilan. Selain itu, saran dari dislenggarakannya kegiatan ini adalah perlunya dilakukan praktek secara langsung bagaimana cara monitoring kualitas air oleh kelompok pembudidaya Desa Kertayasa Kecamatan Cijulang, Kabupaten Pangandaran.

\section{Ucapan Terimakasih}

Termakasih kami ucapkan kepada Bapak Kholil, S.Pi sebagai Ketua Kelompok Pembudidaya Ikan Kawungsari, Desa Kertayasa, Kecamatan Cijulang atas bantuannya untuk mengkoordinasi kegiatan penyuluhan.

\section{Daftar Pustaka}

Hutabarat, R.B. (2011). Sikap Pembudidaya Terhadap Materi dan Media Penyuluhan. Studi Kasus: Pembudidaya Komiditi Belimbing Desa Normanian dan Tiang Layar, Kecamatan Pancur Batu, Kabupaten Deli Serdang. Skripsi. Universitas Sumatera Utara, Medan.

Islami, A. N., Hasan, Z., \& Anna, Z. (2017). Pengaruh perbedaan siphonisasi dan aerasi terhadap kualitas air, pertumbuhan, dan kelangsungan hidup pada budidaya ikan nila (Oreochromis niloticus) stadia benih. Jurnal Perikanan Kelautan, 8(1).

Hasan, Z. (2015). Pemanfaatan Teknologi Aerasi Berbasis Energi Surya Untuk Memperbaiki Kualitas Air dan Meningkatkan Pertumbuhan Ikan Nila Di KJA Waduk Cirata. Jurnal Akuatika, 6(1).

Hikmat, M. M. (2011). Metode Penelitian: Dalam Perspektif Ilmu Komunikasi dan Sastra. Graha Ilmu. 
Koentjaraningrat. (1985). Pokok-pokok Antropologi Sosial, Jakarta, Aksara Baru.

Kkp.go.id. keputusan menteri kelautan dan perikanan republik indonesia nomor 75/kepmen-kp/2014.

Silalahi U. (2015). Metode Penelitian Sosial Kuantitatif. Reafika Aditama, Bandung

Soemarwoto, O. (1983). Ekologi, Pembangunan dan Lingkungan Hidup, Jakarta, Djambatan

Suwartapradja, O. S. (2010). Pranata Sosial dalam Pertanian: Studi tentang Pengetahuan Lokal pada Masyarakat Pembudidaya di Jawa

Barat. Sosiohumaniora, 12(1), 86. 